\title{
年末の闘争儀礼
}

井本英一

本稿は, 『オリエント』Vol. XI Nos. 3-4, 1968 所収の拙稿, 「イラ ン暦の諸問題」をつづけたものである。

先稿では, 古代イランにおいても太陽太陰暦の知識があったらしいこ とを述べた。ことに古代ペルシャ暦ではその名称が旧暦の知識がなけれ ば説明できないものがあることも指摘した。アヴェス夕暦のほかに，そ れと並行して，6つの祭日があり，それは季節と農事に関する名称をも つ 5 つの祭と, 闘争祭とから成っていることも指摘しておいた。 5 つの 祭日が黄経の分点にあたり，これでもって太陽太陰暦のずれを調整して いたらしいことも明らかにしておいた。古代のゾロアスター暦が，かり に旧暦のたぐいではなく，単なる，太陽暦にもとづくVague Yearであ つたとしても，季節と暦のずれを調整するものがなければ，農作業は不 可能である。アル・ビールーニーは，イスラム期の代官で，同一年度内 に当時の暦の上での徵税期と，実際の収穫期の 2 度にわたって徵税した 者のことを述べているが，この暦では農作業は行ないえないのは明白で ある。当時の農民にも，何らかの依拠すべき暦が王室の天文博士から知 らされていたと考えなければならない。農業は国家の大本であるからこ とさらにそうである。

これら 5 つの古代イランの祭日は先稿で述べたようなものであって, その名称も，ゾ教暦で用いられた神格名をとっていない。すべて季節に 関係のある名称である。この 5 つの祭とは別に, 最後の年末に行なわれ るハマスパスマエーダ祭の名称は，これらと関係がない「闘争祭」とい 
う名称である。H. W. Bailey が与えた「ビール祭(秋の終)のあつまり」 という解釈は自分には納得ゆかない。この名称がかりに真だとすると，

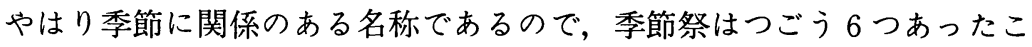
とになる。しかし，これから述べようとする年末の余日の処理に関する 考察によれば，ハマスパスマエーダ祭はやはり季節の調節点としての祭 とは関係のないものである。重要性においては両者ともかわらないが質 的にはことなったものであったと考えられる。

5 つの季節の調節点ガーサンバール(ガーサーンバール)の古代イラン 語は残っていないが, ${ }^{*}$ gātūnām*hampārō と復元できる。意味は「季節 の調節者」である。中期語としてこれが 1 語に熟した形を求めれば，ま ず *gāsūnhambār が得られるであろう。しかし古期語 gātu- は中期語で は gās, gāh となり, その複数形は gāsān, gāhān と定着化してしまって いるので, それは "gāsānhāmbār, "gāhānhāmbār となる。重音省略が 行なわれで gāsāmbār, * gāhāmbārとなる。 パハラヴィー語文献では gā

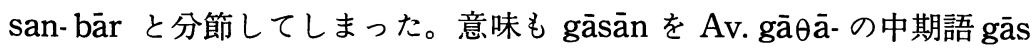
の複数とみなし，-bār を中期語 burtan bar-と関係づけてしまった。す なわち「Gāthā-tragend，ガーサーを持った(祭日)，ガーサーを唱える (祭日)」というふうに解釈されている。この伝統的解釈は, パールシーの 学者や欧米のイラニストにも無条件に支持されている。

この分節のしかたには疑問がある。インドのパールシーに伝わる近代 ペルシャ語には gāhambār という別形がある。これを "gāhāmbār の異

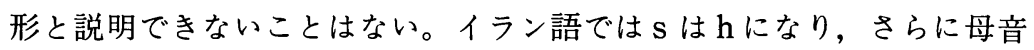
間では消える傾向にある。このばあい, gāsān- が gāhān- となり, gāhānという異形をもつと考えるのである。そこで, gāhambār も gāsambār も同じ意味であるとする。しかし， gāhambār を gāh-ambār と分節す ると, 前肢は単数としての ${ }^{*}$ gātu- , 後肢は *hampāra- と解釈できる。そ こで, gāhambār の古い段階の形は ${ }^{*}$ gāh-hambār となる。意味は「季節 
の調節者」である。つぎに，-bar と分節したばあい，それを burtān bār「持つ, 運ぶ, bear」と関係づけるのは問題がある。 OPers． asabāra$\ulcorner$ horseman」, Pahl. asaßār, Pers. suvār における -bāra-, -bār が bar(=Skt. bhar-)の派生形である以外は古代イラン語では「tragend, having」を意味する語は - bara-，ときに-vara-であらわれる(Bartholomae， Air Wb. 1942-43の逆引表を参照されたい)。母音度の高い前者のばあ い「tragend」の意味をもっていたのかどうか疑がわしい。Pahl.bārak, Pers. bārah は OPers. bāra-に対応する語であるが，「駿馬」の意味を持 っているからである。 -bārを「…に富んだ」と解釈すると，それは場 所を指す語にしか使われないので困難である。 Hindūbār「インド」, daryābār「大洋」, jūybār「諸川の合流する所」など。「Gāthā-tragend」 の意味を考えるならば，パハラヴィ一語では gāsānbar でなければなら ない。

先稿69-70ページの表における数字，41-45，101-105，176-180， ‥はイラン学では何らの疑問もなく，日数のこととしている。拙稿で 述べたように，それは黄道の分点である。アヴェス夕の Āfrinakān i

Gāsānbār， 7 以下は上の数字と関係ある個所である。たとえば，7の アヴェス夕語原文は次のようなものである。

pančāča ča $\theta$ warəsatəm mai $\delta$ yoi. zarəmayehe ašahe vahištahe da $\theta$ ušō $\cdots$

Ch. Bartholomae の訳，およびそれをそのまま受けついだ F. Wolff の訳は

Fünfundvierzig[Tage sinds bis zum(Haupt)tag] des Mai $\delta$ yōi. zarəmaya[im Monat] des Aša Vahišta[am Tag] des Schöpf ers....となっている。この訳文にはかなりの無理がある。原文は直 訳すると第45(中性，主格，単数) ・ M. Z の・AVの・主の…である。 アーフリーナカーン 8 以下も同様に序数詞が用いられている。日を数 
えるのにアヴェスタでは xšapan-「夜」をもってする。「夜」がとる格と 数とはさまざまなものがあるが，日数を示す数詞は基数詞であることに 注目しなければならない(Ch. Bartholomae, AirWb., 548－9 を参照さ れたい)。属格であらわれる M. Z は所属の属格とみなければならない。 そうすると $2 つ の$ 解釈が可能である。

1. 主の $\mathrm{AV} の \mathrm{M} . \mathrm{Z}$ には第 45 が。

2. 主の $\mathrm{AV} の \mathrm{M} . \mathrm{Z}$ には第45日が。

1.は黄経の度数と考える。2.のような語法で序数が用いられるかどう かは問題である。バルトロメー・ヴォルフの訳はこの点で苦心している らしく，けっきょく上のような訳になってしまった。Grundriss, p. 676 に紹介されているCamaの説は, 最良の, 注目すべき解釈とされるが, 太 陽暦だけをもとにしていることと, Vague Year ではなく新らしいり゙数 暦によっていることと，季節の区分法が恣意的であることから自分には 納得できない。

Gāh あるいは gās というのは，このような季節の重要な折目であった。 ガースはさらに 1 日の区分とも考えられていた。アヴェス夕時代からそ れはあり，Hāvani(夜明けから正午まで), Rapi $\theta$ wina(正午から3時ごろ まで), Uzayēirina( 3 時から夕暮まで) などの 5 つの区分があった。ア ヴェスターパハラヴィー文献の伝承では，それは線状の時間を指してい るようであるが，起源的にはそれぞれの線の始まる時刻を指したものと 考えられる。アラブの礼扯の回数は，マホメット時代には 1 日 3 回であ つたのが, のちに 5 回になっているが, Goldziher はこれをペルシャの 影響とみている (Encyclopaedia of IslamのṢALĀT の項を参照された い)。仏教では法華経を 1 日の 5 つの時に説教する惯わしがあるのをみる と, 文献の初出だけでは済まされない問題を含んでいるような父がして ならない。

年末のハマスパスマエーダ祭は361日ー365日の 5 日閒とされるが，こ 
れにはいろいろな問題がある。上述の 5 つの季節祭が 5 日間祝われるの は，黄経の72分の 1 にあたる中国の候と関係があると考えられる。しか し年末祭の 5 日は暦の上での閏の処理の問題と関係があると考えられる。

年末祭は年末の 5 日間とは限られていなかった。すでにアヴェス夕の 時代から年末の10日間がハマスパスマエーダ祭と考えられていた。上記 アヴェスタのアーフリーナカーンではハマスパスマエーダ祭は 5 日間と なっているが，それよりは起源の古いヤシュト13.49 では10日間とされ ている。この期間中に祖霊がその住居からこの世にやってきて，10夜の あいだ选遙する。アヴェスタでも，やはり起源的には古いヤスナでは， 5 つの季節祭と年末祭の 6 つの祭が同列にあつかわれている。年末祭の 日数に関しては古くから浮動があったことがわかる。パハラヴィ一文献 では，10日間の年末祭の方は，祖霊に重点が置かれてフラヴァルティー カーンと呼ばれるようになり, 後半の 5 日のみをガーサーニークの日と して，特別に神聖な日とするようにしている。一種の習合的なやり方と 考えられる。

ゾロアスター教の伝承では, いずれにしても年末が祝われてから新年 にはいったことがわかる。ところが,アル・ビールーニーの時代 $(10-11$ 世紀）には，新年の 1 日 -5 日が平民の新年， 6 日-10日が貴族の新年 というようになっており，ゾ教の伝承とのずれがみられる。祖霊はこれ ら10日間の新年にあの世からこの世にやってくる。ペルシャ語で 1 月の ことを Farvardīn（祖霊の[祭]）というのはこの事実に即したものである。 パハラヴィ一語の 1 月は Fravartīn であるので，パハラヴィー文献の記 載とは別に，すでに慣習としては，10日，5 日の年末祭は新年 1 日ー10 日の新年祭となってしまっていたと考えなければならない。現在のイラ ンの新年は 1 日から 12 日までを祝い，13日は郊外に出て家を空ける風習 がある。13日は不吉な日として夕ブーとされる。この日は，うちにいる と悪霊に害されるので，それを避けるために郊外に逃れるのだと人びと 
は考えている。しかし，不吉なタブーと考えられる日は神聖な日であり， かつてはこの日が新年の日であったと考えなければならない。先稿で引 用した万葉集 3460 の新賞歌にみられるように，年の変り目には人は戸 外に出たものである。現在，われわれが新年を社寺で迎えるのと同じこ とがイランではこのような形をとって行なわれているのである。新年祭 を戸外でやる習慣のあった古代では，それが再生のための招魂儀礼であ ったので，Uとは必然的に家を空けて外に出なければならなかった。13 日の [もとの]新年は, 年末の閏の処理から生じた新年であると考えられ るわけである。西欧社会で, 13 人が食卓につくことをタブーとするのは, キリストと 12 使徒の最後の晚さんの故事にもとづくと考えられているが， 13の夕ブーはもっと古いところにあると考えられる。船乗りが13日の金 曜日に入港するのをきらうのは周知のことであり，この日に旅行するこ とに不安を感じる人もある。13日の金曜日(の夜)が安息日にあたり，新 年であった遠い昔の神聖さの名残りかも知れないのである。文献以前の ことは推測する以外にない。

Narshakhīのボ八ラ史（10世紀）のペルシャ語抄訳によると，ボハラ 近辺の町ヴァラフシャでは毎年15日間の市(いち)が立ったが，これが年 末にあたったときは20日間行なわれ，21日が新年で，農民の新年と呼ば れた。マギたちの新年は 5 日ほどおくれていた(Richard N. Frye, The History of Bukhara, 1954, p. 18を参照されたい)。この記事とアル・ ビールーニーの記述を対比してみると次のことがわかる。農民・平民の 新年は 1 日ー 5 日まであって，5 日が本式の新年であったこと，マギ・ 貴族のそれは 5 日おくれていたこどである。これは新年を 1 日，6日と していない点で注目すべきものである。

なお，興味のあるのは，ボ八ラ史のいうような市が新年に先立ってた つことである。ボ八ラ史の記述では，市はかならずしも年末に終るとは かぎらないようであるが，おおよそ年末の 15 日間が市で，新年から 5 日 
までは農民の新年であったことはたしかである。交易は起源的には招魂 の儀礼から出たもので，大和の椿市の交易と，かがい，社寺の縁日の市 などと通ずるもので，新年祭に入る前の行事である。いずれ稿をあらた めて論じたい。

先稿の75ページの表でみられたように，ゾ教暦の月は主・オーフルマ ズト（アフラマズダー）の日で始まり，各週の始めも主の日で始まった。 30 日 $\times 12$ 月 $=360$ 日のほかに 5 日の閏月があったが，これには神格名を つけていなかったと考えなければならない。サンスクリットに残ってい る anāmaka-「閏く無名月」は, 曜日と月名の無名の状態を指したもので, 古代ペルシャ暦10月の Anāmakaも起源的には同じである。これは先稿 で論じた。欧米の学者は, ゾ教暦10月は「主の月」であるので, これと 古代へ暦10月のアナーマカを対比して，「無名」=「主」とするが，そう すると, Anāmaka とサンスクリットの anāmaka-との関係が断たれて しまう。日本の神無月とこの 2 つの月名を対比すれば次のことが考えら れる。太陽太陰暦も非常に古くは年末に閏を置いていて，閏が年末にで はなく，新年として起算されるようになったのではないか，ということ である。これは例えばイランの暦にもみられるものである。古代ペルシ ヤ暦10月のアナーマカは新年に繰り入れられていたのか，事実上の年末 の閏であったのか不明である。古代イランの暦は名称の上からみると， いくつかの太陽太陰暦の名称をとどめているが, かりにすべてが早い時 期に Vague Year に移行したとしたら，5日の閏はとうぜん12月のあと に置かれたと考えられる。先稿70ページのエジプトの暦表でも， 5 日の 閏は 12. Mesori のあとにくるが，この暦の時代には 4. Khoiakの最後の 5 日が重要な日で，5.Tybi 1 日が新年であった。Khoiak 26日一30日は したがって，かつての閏であったと考えられる。そうすると，古代イラ ンの10月も，かつては月末に重要な閏の名残をもっていて，それが月名 の起源となったとも考えられる。こう考えると月名の説明と事実上の年 
末の閏の説明がつく。

イラン人は新年13日を不吉な日と考えているが，もうひとつ，年末 の最後の火曜日の夜（水曜日のはじめにあたる）をも，もっとも不吉な 日と考えている。この日はペルシャ語で čahār-šambe ye sūrīという。 安息日である土曜日シャンべから数えて 5 日目にあたる。この日も，か つてはイラン人は安息日と同じょうに，いっさいの活動を中止して戸外 へ水を取りに出かけた。17世紀の Olearius らの記述に関しては $\mathrm{H}$. Massé, Croyances et Coutumes Persanes, 1938, p. $148 \mathrm{ff}$.を参照さ れたい。この日に行なわれる行事には，いわゆる正月行事と同じものが 多くみられる。かつてはこの日が年の変り目であったと考えられるので ある。つまり，安息日としての主の日から数えて 5 日目の新年 5 日にあ たるわけで，アル・ビールーニーやナルシャヒーにみられた新年 5 日の 農民の新年にあたるわけである。どうしてこれが新年以前に祝われたか となると,やはり暦の問題となろう。年末 5 日の閏の「無名月」の意味 が忘れられて，その第 1 日が「主の日」にあてられ，新年 1 日が第 4 シ ヤンべと考えられるような時代や地方があったにちがいない。

エジプトでは Khoiak 26日ー30日の5日はオシーリスの日で，オシー リスの復活のためのさまざまな秘儀が行なわれた。翌 Tybi 1日はSed 神の祭で, ファラオの即位礼はこの暦の時代では,この日であった。26日

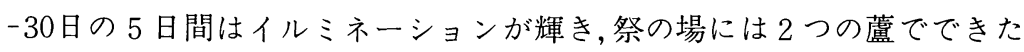
Festival Hall と，途中で衣裳なおしをする居室 Palace とがった。ち なみに，アヴェス夕のヤシュト13・45でも，イランの祖霊は年末に戦闘 を行なうが，その戦場は光り輝いているとある。エジプトの即位礼にお いても，大嘗祭のユキ殿，スキ殿に対応するDual Shrines があったこ とに注目したい。ファラオは1日のセドの祭でホールスの目をとって再 生する。ホールスの目はオリエント学者にはおなじみのもの, わが国の 例を引けば，皇大神宮の神鏡とそれをおさめる棈円形の黄金の御樋代が 
これにあたるものと考えられる（拙稿「十字表象の研究」、『西南アジア 研究』, 1969 を参照されたい)。Khoiak 最後の日にオシーリスの像は埋葬 される(H. Frankfort, Kingship and the Gods, 1948, Chapter 6 を参照 されたい)。オシーリスの像は泥に種子をこね合わせて作られたが, プト レマイオス時代には，この像の埋葬は Khoiak 月18日「大地を耕す日」 に行なわれた。この日は，いかなる播種祭とも論証できる関係にないと する。Tuthmosis III世時代のテーベーの墓のテキストでも，この月の18日 は大麦をしめらせ，オシーリスのために床を敷く日とされている。この 日も農業活動との関係ではなく，オシーリスの葬儀の意味でのみ考之ら れている(H. Frankfort, 前掲書, p. 392, note 49を参照されたい)。 大麦を水にひたして発芽を助けるのは農業に関係のあることである。 オシーリスの死と復活のモチーフがよくあらわれている。H. Frankfort はこの点に，他の個所でも，留意しないのが目につく。

Khoiak 月の末から逆に算えて12日目，Tybi 1 日からは13日目にオシ 一リスの再生儀礼が行なわれたことは意味がある。かつてはこの日が年 の変り目，つまり新年であったと考えられるのである。Tybi 1日はイラ ンふうにいえば13日の家空けの日となる。キリス卜教ふうにい之ば，ク リスマスと 1 月 6 日の主顕節のようなものである。

バビロニヤの新年も似たような構造である (以下, S. H. Hooke, Babylonian and Assyrian Religion, 1962, p. $101 \mathrm{ff}$. のバビロニヤ新年のテ キストによる。なお，H. Frankfort,前揭書 p. 317 ff. を参照されたい)。 バビロニヤの新年祭は Nisan 1日から12日までつづいた。 5 日は贖いの 日で，王は Marduk に羊の犠牲を捧げ，告白して罪のゆるしを乞う。6 日に，杉とタマリスクでできた 2 体の像は首を斬られ，火の中に投げ込 まれる。つまり，王の死を象徴する儀礼は 6 日に行なわれるのである。 7 日には幽閉された Marduk の解放が行なわれる。9日に，バビロン郊 外の Akitu神殿への行幸がある。Akituはおそらく，その上部に木造の 
小屋が設けられ，ヘーロドトスのいうように，そこで聖婚が行なわれた Ziqqurat のことであろう。12日に神々はそれぞれの神殿に帰還し新年祭 は終る。

バビロニヤでは新年 6 日が重要な日であった。この日には，エジプト のファラオの像がそうされたように，バビロニヤでは王は煩を神官に強 くなぐられている。H. Frankfortは，ファラオの像を打つのは彫刻者の 完了の最後のタッチ, the Opening of the Mouth Ceremonyのタッチ とするが不可である。通過儀礼における試練の一種であることは民族誌 的な比較をしてみるとわかることである。ゾロアス夕一教における通過 儀礼は, デーンカルト第 8 巻の Pāčak Nask にみられる。M. Molé, Culte, Mythe et Cosmologie dans 1'Iran Ancien, 1963, p. 85 の要約 によると，それは, 動物の犠牲, 信徒のつどい, 告白と罪の宥し，イ二 シエーションの繰り返し，神との語らいの諸要素からなっていて，年末 5 日の聖日に行なわれる。これらの諸要素はアヴェス夕のガーサーにも パハラヴィー語文献にもあらわれる。

読者はここで，先稿で述べたアラブのモハッラム10日，日本の11日正 月(鏡開きなど)などと同じように，新年をはさんで, ·前後 $5-6$ 日, 1013日の幅で，もっと新年らしいもの一古い暦の残り一があることに 注目されたと思う。

中国，日本の新年行事をみると，やはりこういった古い暦の残りがみ られる。いっぱんに，古代オリエントで閏として年末に置かれた余日は， 極東では新年以降にずらされている。古代イランの年末の余日が，中世 以降は新年のがわに入っているように。中国暦の新年 1 日から 7 日の人 日までがこれにあたるものである。正月 1 日を鷄となし，2 日を狗とな し，3日を羊となし，4 日を猪となし， 5 日を牛となし，6 日を馬とな し，7日を人となし $\cdots$ と荊楚歳時記にいっているように，6日間のそ れぞれの日々は動物と関係づけられているが, 7 日は人と関係がある(守 
屋美都雄, 『校註 荊楚歳時記』，昭25，37ページ以下を参照されたい)。 正月 7 日の行事で注目すべきことは， 7 種の菜でもってあつものを作る こと,人勝を作ること, 高きに登って詩を賦すことである。いわゆる七く さがゆのようなあつものではないが，イランの新年行事のUとつに Haft

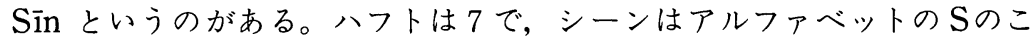
とで，S ではじまる 7 種の食用植物を新年に用意するのである。これを 用意するのは新年に移る直前である。くわしくは，H.Massé の前掲書， 156ー157ページを参照されたい。イランの例でみられるとおり，七くさは 農耕儀礼としての行事で，年の移り目に祝うのが本筋である。正月 7 日 の人日が古い年の変り目であったことがうかがえる。この日に人勝を作 ク，これをびょうぶに貼ったり，かんざしにつけたりしている。アルテ ル・エゴが 7 日にあらわれるのは，この日が古い年の変り目であったこ とを示している。日本では, 大晦日の形代としてあらわれるものである。 エジプトのオシーリス像は上に述べたように，やはり新年と考えられる 時点において作られるし，また，こわたれるのである。荊楚歳時記によ ると，正月 1 日の鶏と 7 日の人の像だけが作られ，その中間の諸日には 牛馬などの像は作られていない。鶏の像についてはそれじたい問題があ るが，中国では 2 つの新年が習合してこのような形式をとったというこ とは否定できない。同じような形式がイランの新年にもみられることは 上に述べたとおりである。古代のメソポ夕ミヤにおいてもそうであった。 後述する日本の例をみられたらさらに明白となるであろう。正月 7 日の もうひとつの特徵に登高賦詩がある。日本で，歳時記の季題になってい る大晦日の岡見はこれにあたる。新年を迎えるにあたって䓂をさかさに つけて，岡に登り，ふり返って自分の村をみる行事である。裏がえしや ふり返りのような，さかさの表象がみられるのは通過を意味するもので, 登高はおそらく，神に接するためのものであったと考えられる。イラン の正月13日には，とくに高きに登るという習慣はない。首都テへランの 
ような山麓のオアシスならば，郊外の山の手に出かけることも可能であ るが，すべてがそのような立地条件にはない。しかし，神と接するため に家を空けることは共通している。登高はこのほか，日本では 3 月 3 日， 卯月 8 日にも行なうが，いっけん新年とは関係のない，他の農耕儀礼の ようにみえるが，山の神を迎えるための行事であることにはかわりがな い。いっぱんに登高や野遊びの行事は戸外での食事をともなう。イラン 人のように，この日を郊外の墓地で過し(新年においてもそうである), 祖先と共食するばあいは，古い神人共食の形式がよく保たれている。

年末の余日を処理するばあい，新しい暦がかぶさってくると，新しい 暦の新年のあとにこの余日がくる傾向がみられる。そして，余日のあと

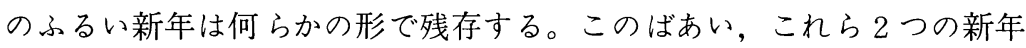
が，前の祭と後の祭のような形式をとって残るか，このような形式をと らないで，内的比較からのみでは分析が困難な祭日として，いっぽうが 残るかしている。

日本のばあい，松の内が 7 日までであることに注意すべきであろう。 ほかに小正月の15日まで，あるいは13日までとさまざまな慣習がある。 6 日を年越の日とするのにも注意すべきである。 七日正月という考え が, 七くさがゆの日というほかにあることは, 古い年の変り目がこの日 にあったというひとつの証拠である。そのほか10日，11日などがそれぞ れ正月と称せられるのをみると，日本の暦が中国から渡ってきたもので あるとしても，じつにさまざまな層があることがわかる。

別に，中国の臘日を考えなければならない。この日は年の最後の日 で, 臘祭の行なわれた日で, 臘と猟とは通ずるので, 動物の犠牲を行ない, 人間への変身を成就せんとした祭日であったと考えられる。正月 1 日か ら人日にいたる各日に動物が配せられていたのを想起していただきたい。 ところが湖南の荊楚地方では, 臘日は12月 8 日になっている（守屋氏, 前掲書, 185 ページ以下の詳注を参照されたい)。人日よりは1ケ月はや 
い年の変り目があり，それが同時代の暦に並存していることがわかる。 日本ではこの日は事始めの日とされ，正月を迎えるための前の祭と考え られている。もうひとつの事始めの日は12月13日である。芸能界，花柳 界などでは，この日に年始を行なう風が残っている。京都の祗園の事始 めはことに有名で, 歳暮御祝儀の日でもある。昭和 45 年10月の八王子市 ・大学セミナー・ハウスでの日本オリエント学会大会での足利惊氏先生 の御教示によれば，赤穂義士が討入りの前日である13日に，足利邸に年 始(あるいは年末であったか失念) のあいさつに訪れている。

このように，比較しながら列挙してくると13日，8日の事始めは，正 月の準備のための事始めであったり, 縁起の先取りとしてのものではな かったことがわかると思う。メソポタミヤとイランの年末の余日, 新年 との比較から， 5-6日と，10-13日くらいに2つの年のわかれ目があ らわれることもおのずと首肯されよう。これらは，けっきょく，1年を 365 日にするか，360日にするか，354日にするかなどの問題と関わる ものであって，慣習的なおおよその余日がはみ出して過去の残存として 残っているものと考えられる。残存物ないしは，はんぱ物の中にかえっ て本質があるとする哲学は多くの面で説得力をもつものであると自分は 考えている。

アヴェスタ・ガーサーには, 終末における善悪両軍の戦闘において, アフラ・マズダーが善軍に味方するよう祈願される個所(複)がある。こ れらの個所に出てくる両軍は, アヴェス夕語 rāna-, rạna-, spāda-の双 数である。Av. spāda-はガーサーでは spādāとして 1 ケ所に出るのみで ある。Av. rāna-, rạa-にみられるように, 長母音 ā と鼻音化短母音 ąが 並存していることに注目したい。これらの語は Skt. rana- 'battle, combat'と対応する。ただし，サンスクリットには長母音をもった ${ }^{*}$ rānaはない。OP. spā $\theta$-とAv. spa $\theta$-にみられる母音の長短もこれに類するも 
のと考えられる。

OP. hamarana-「戦闘」, Av. hamarəna-「戦闘」は hama-rana-と分 節すると, rana-( $=$ spā $\theta$ maida- ) がよく浮び上がってくる。同じ意味 をもった Ved Skt. samáraṇa-をVed Skt. samará-'Zusammenkommen' つまり， sam + ar の合成語の派生語とみて， sam-arana- と分節するこ とが行なわれているが(Grassmann)，再考を要する。アヴェス夕語も， ham-arəna- (Bartholomae) と分節されている。OP. hamarana- も同じ ように分節するのであろう。しかし， Ind-Iran. rana-は戦闘ないしは戦 闘員をあらわすことばで, 同じ語根 ar-「動く」から出た arana-は「遠 ざかった，遠方の」の意となる。イラン語の hama-spằ $\theta-$ maida- も hama-rana-も，構造的にも意味的にも同じものなのである。

アヴェスタ語ハマスパスマエーダのパハラヴィー語訳は hāmspāh ravišnih である。ブンダヒシュン $87_{19}-88_{2}$ の説明では，人間のフラワフ ルが一団となってやってくる，とある。民俗学でいう祖霊の群行来訪に 一致するもので，このさい，フラワフルも祖霊も武装していると考えら れている点, 注目にあたいする。パハラヴィ一語訳は, hāmspāhを群行 ととク，アヴェス夕語のマエーダ（前掲，拙稿89-90ページを参照され たい）の訳は ravišnīh を来訪ととっているので，群行来訪の概念によく 合致する。しかし，パハラヴィー語訳は Av. maēda-を正しく訳してい ない。祖霊は武装して群行来訪し，この世で敵と闘争するのである。ア ヴェス夕語ハマスパスマエーダは, 群行来訪ではなく, 両軍の闘争を意 味することになる。パ語訳はこの祭の特徵のひとつを語源俗解によって 説明したものに過ぎない。

H. Massé, 前掲書，160ページによると，テへラン州西部のターレカ ーン地方では, 1 月 13 日の「戸外に出る13日」に, この地方の 2 つの村の人 たちが谷の両側で悪態をつき合う。悪態は儀式としてのもので,すぐに仲 直りをする。それは, 新しい年に不幸がこないようにするためだと村人は 
考えているようである。谷の両がわに陣どるのは，川の両がわに陣どる のと同じことであり，それはさらに異族間の闘争の布陣でもある。日本 の例をとれば，新年ではないが，夏至前日の虫送りの行事では，子供が 竹にひと形をつけて村境の川まで進み，対岸にいる，やはク隣村からや ってきた子供たちと悪態をつき合う。子供の遊びは大人の遊びの模倣と いう公理からすると, 古くは村人どうしの闘争儀礼であったと考えられ る。季節の折目にUと形を流したり，棄てたりするのは重要である。工 ジプトでは, 新年の 12 日前から用意されたオシーリス泥像が神官にふみ くだかれた。王位更新儀礼では，ファラオの像を，のみを入れて，き損 した。村どうしの争いの例として, やはり夏至前日の鞍馬の竹伐り会が ある。この行事は, 近江座と丹波座の法師が雌雄の蛇になぞらえた 4 本 の竹を伐る闘争儀礼である。この行事では，民族誌に多くみられる竜と の直接の闘争ではなく, 両村の闘争が主要なテーマとなっている。竜や 蛇の表象するものには複雑なものがあるので省略する。ペルシャの夏至 祭で水かけと悪態の儀礼が川辺で行なわれていたことは，17世紀のDella Valle によって記述されている(H. Massé, 前揭書, 163 ページ)。同書 159 ページには，1月13日に，少年たちが相撲をとったり，はしゃぎまわ つて遊ぶとある。正月の双六，羽つき，かるたのような競技に類する闘 争儀礼は，イランの正月1日には行なわれないで，13日に行なわれ，そ の日のとなえごとに「新年うんぬん」の語があることにも注目したい。 さきに，中国の臘日，つまり年末が12月 8 日であった暦の例をあげ， 日本の事始めが12月 8 日あるいは13日であることをあげた。イランでも, 古く12月13日が特別の日であったと考之させるふしがある。エステル書 によると，アハシュエロス（クセルクセス）王の治世に，ハマンはュダ ヤ人をすべて殺そうと謀り正月13日に王に詔勅を出させるが，エステル の機知でハマンは樹に懸けられる。ペルシャの習慣では, いちど出され た詔勅は取消せないので，エステルの養父モルデカイをして，王はュ夕゙ 
ヤ人がかれらの敵と戦って生命を守ってよいとの詔栜を送らせた。かく して12月(アダル)13日と14日に，ユダヤ人は 7 万 5 千人以上の敵を殺し た。14日と15日はユダヤ人の祝日プリムとされた。プールとは「くじ」 の意で，ハマンが殺りくの日をくじで定めたからだという。

エステル書の記事から，われわれはハマンが 12 月のこの日にユダヤ人 を殺りくして新しい時代にはいろうとしたことをうかがうことができる。 この日の特徵が合戦 - 闘争であることは，次にみる回教暦 1 月10日の特 徵である合戦とも一致する。つまり，古代のペルシャにも12月13日ごろ に年末がくる暦があったということが考えられるのである。ないしは， ユダヤにもあったと考えられる。

黙示録にでてくる，地上の王国の終末の善悪の闘争の場としてのハル マゲドンの思想が前 6 世紀のキュロスII世からアレキサンダーまでの200 年間のペルシャ帝国のユダヤへの影響であると必ずしも考えなくてもよ いであろう。象徵的な終末を，この世でドラマに表現するばあいは，年 末しかない。これがアダール月のプーリーム祝日に，ペルシャ人を悪の 象徵としてかれらとの闘争を演じたのか, それとも30日に別のドラマで 演じたのかは資料が現存しないので何ともいえない。

ギリシャ語ハルマゲッドーンは通説のように，メギッドーンの山を音 訳したものであろう。メギドは先史時代いらいの要衝で, メギドの平原 は一その中央を川が貫流している—カナンやイスラエルの王たちの 決戦場であった。ヨシア王はファラオ・ネコと戦って戦死している（歴 代志下 $\left.35_{22-4}\right)$ 。これら王たちの合戦の日がいつであったのかうかがうこ とはできないけれども，教暦の12月13日と正月 1 日と 1 月13日とが聖日 とされていたと考えられるので，王位更新祭を行なおうと思えば，12月 13日に闘争をする古い慣習にしたがわざるをえないであろう。教暦 7 月 Tišrī が政暦 1 月にあたっており， 7 月 1 日が新年とされる暦が並行し ているが，この暦では 7 月10日が贖罪日で聖別されている。この日はつ 
ぎにのべるアーシューラーと関係がある。闘争はパレスチナがわだけで 重視されたわけではない。ユダのヨシア王とメギドで対したエジプトの ネコにも，聖戦の日取りに関心があったと考えなければならない。 $\mathrm{H}$. Frankfort, Kingship, pp.178-9には, デルタのふたごの町Pe と Dep の住民がパピルスの茎でもって闘争する儀礼をあげている。上にあげた イランのターレカーン地方の両村の闘争や，日本の鞍馬の竹伐りと同じ ことが行なわれていたのである。エジプトの装飾石棺に，新年の Sed祭 でDjed 柱がたてられ，別の欄ではもぎ戦が絵かれているように（E. O. James, The Ancient Gods, 1960, p.136の Fig. 8.を参照されたい)， 新年と闘争儀礼は深い関わりをもっている。

ツーキュディデースII.15によると, 古いディオニュシアはアンテステ ーリオーン月の 12 日に行なわれた。この祭はのちには 4 月に行なわれて いるが，アッティケー暦 8 月のアンテステーリオーンは $2-3$ 月の早春 の候であった。

祭は 3 日間行なわれた。第 1 日は新しいブドウ酒の壼の口が開かれた。 第 2 日は死者の霊が帰ってくるので不吉な日と考えられていた。第 3 日 の終りに死者の霊はあの世へ帰っていった。この日に「鍋あらそい」と いう闘争儀礼が行なわれている。祖霊が帰る前に，かれらとの饗宴がな された。これらの日々は不安と緊張に満ちたタブーの日々であった）J. E. ハリソン・佐々木理訳, 『古代芸術と祭式』, 1964, 123-4 ページ ;

W. Smith, A Classical Dictionaryを参照されたい)。 アンテステーリオーン月はアッティケーの暦では8月になっているが, 自分が上来述べてきたことからみると，それは古くは年末の12月であっ たこと，ア月の $12-14$ 日は年の変り目であったこと，この 3 日は古い閏 の残存であることが明らかになったと思う。中国や日本やパレスチナの 12月13日が古い年の変り目であったのはすでにみてきた。先ギリシャの 伝統では12月14日が臘日となっており，この日に闘争が行なわれている。 
ギリシャのこの「花('anthos)まつり」も，民族誌的にみれば早春のもの でなければならず，おそらくは春分を起点とした暦が確立したころの， 古い年の変り目の残存であろう。祖霊の来訪がこの祭では中心的なテ一 マで, 神人共食の再生儀礼に終っていることに注目されたい。

北アフリカにおける古代の闘争儀礼に関しては，へーロドトスがいく つかを伝えている。Herod. IV.180によると，現在のアルジェリヤと考之

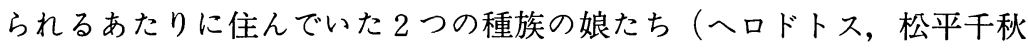
訳，昭42，223ページ注(2)を参照されたい）が武装して，アテーナー女 神の年祭でふた組に分れて争う。ここでは，両種族の女性軍の闘争が述 べられている。この節の末尾に述べられた記事からみると，これらの種 族は母系社会に属していたと考えられるので，女性どうしの闘争となっ たとも察せられる。あるいは祭神が女神であったのでそのようになった のか。しかし，これには民族誌的にいくらでも反対の例があげられる。 自然民族の間では，女性軍が男装して戦う例もあり，アフリカにもその 例が報告されているので（吉田禎吾，『未開民族を探る』，昭40,187ぺ ージを参照されたい)，どのような服装をしていたのか興味がある。

Herod. II.63では，エジプトのパプレーミスの社における祭司と信徒 たちの棍棒の打ち合いの儀礼が述べられている。II.60では, ブーバステ イスのアルテミスの祭では, 男女が船にのって出かけるが，町を通ると きには，船の女たちは沿岸の女たちをひやかし悪態をつく。II. 170-1 では，サイスのアテーナー女神（イシス）の神殿にオシーリスの祠堂が あり，そのそばの池で，夜にこの神の受難劇が行なわれた（へーロドト スは，この秘儀については，詳細を知ってはいるが，口を慎しむことに しょう，といっている)，とある。

これらのエジプト人の祭がいつ行なわれたかはへーロドトスはいって いない。II.59によると，エジプト人は国民的大祭をしばしば行なってい るが，最大のものは，上に述べたII. 60 のブー・バスティスのアルテミスの 
祭である。そのほかに 5 つの大きな祭が行なわれている。 ヘーロドトスはオシーリスの祭のことをいっていないが，アルテミス 祭につづいてイシスの祭をあげているから，最大のアルテミス祭とはオ シーリス祭のことであることがわかる。アルテミ不祭は年末から新年に いたる祭であったのであろう。あとの 5 つの祭は, イランのガーサンバ ルと同じように，黄経を分割した定点上の日付に行なわれていたのかも 知れない。

ブーバスティスのアルテミス祭の船中の人と対岸の人との悪態のつき 合いは，寝屋川をさかのぼって野崎まいりをした江戸時代の大阪の人を 思いおこす。年の変り目の闘争儀礼が野崎観音まいりのばあいは，春秋 2 回の法会で行なわれているわけである。悪態祭が年の変り目に行なわ れるのは，正月元旦の足利市最勝寺の悪態市，12月14日に行なわれる茨 城県の岩間悪たれ祭，大晦日の豊川稲荷喧嘩参籠など，あげればきりが ない。マナとしての祖霊が武装してこの世にやってきて（このことじた いドラマの要素を含んでいる), 活力のなくなったこの世のたましいを追 い出し，この世を更新するという観念は，それを人間が演じたばあいは 闘争儀礼の形をとったのは自然であったと考えられる。年末のはんぱな 閏が認識されだした時期には，不安と緊張がこの上なくたかまったこと であろう。闘争は宇宙論的に発展したにちがいない。半族のそれぞれが， 自分が宇宙論的な勝者であると自負して，この時期を闘争でもって過し たと考えられる。やがて儀礼的なものとなったことは，民族誌の諸例の 示すとおりである。両村，両種族で争う通過儀礼の古い型は，半族どう しの争いであったのではないかと考えられる。幽閉された女子の解放と 神聖婚におわる妻あらそいは，外婚的半族の儀礼として年の変り目に行 なわれるものなのであろう。

G. Widengren, Die Religionen Irans, 1965，46ページには興味ある 著者の説がある。それによると，アヴェス夕ではスラエータオナは女性 
の解放者としてあらわれるが，ヴィシタースパも同じである。ヤシュト 13.99-100では，かれは，つながれたダエーナーの鎖をほどいている。 ダエーナーは，その本質がアナーヒターの本質とは究極的に等しい，ア ナーヒターの分身である。この語はリグ・ヴェーダ V. 30.9 にみられる サンスクリットの dhena「牝牛」と同じもので，このスタンザの前半で は，牝牛は「婦人」の語であらわされている。インドラが牝牛を解放し たことと女性を解放したことは同じことをいっているのである。

竜殺しのエピセットをもつインドラの闘争の相手は竜であり,女性(牝 牛）は竜の所有から解放されてインドラの有に帰すことになる。イラン では，そのほかに，アジ・ダハーカがイマを殺したとき，イマの所有す る 2 人の娘を奪う例がある。アジ・ダハーカが上記のスラエータオナに 殺されるとき，上にみたようにダエーナーが解放されている。これらの 伝統は，のちに述べるアーシューラーのさいの俘虜の婦女子の解放にも うけつがれていると考えられている。

メソポタミヤの新年祭では，「囚えられた神の解放」がひとつの大きな

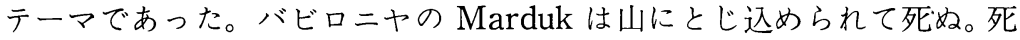
ぬといっても，再生を前提としたものである。シュメールの Lillu は女 神が嘆くなかを，囚われの家から答えている。リルの妹は，イシュタル がタンムズを訪ねて「降り」て行くのと同じように, リルのもとへ「降 ク」て行く。マルドゥクが山にかくれると，バビロンの町はそのために 大そうどうになる。町では人々は闘争を始める。この闘争が新年の何日 に行なわれたかにつ、ては記録がない。山に囚われの身となった神が解 放されるモチーフは前 3 千年紀中葉の円筒印章にもみられる。ここでは， 解放者は弓をたずさえた男神で，女神がつきそっている（くわしくは， H. Frankfort，前掲書，321ページ以下および Figs. 50，51を参照された w)。

インド・イランでみられる「婦女子の解放」では, 男神どうしの闘争 
が行なわれたが，メソポ夕ミヤでは男神が俘囚となっていて，女神をと もなった男神によって解放されている。イランにも，ギリシャにも同じ タイプの神話はある。ファリードゥーン（<スラエータオナ）はダマー ヴァンド山に幽閉されるが，竜を殺す者（イラン王）によって解放され る。このサーサーン朝の即位儀礼におけるドラマでは，アヴェスタ・ヤ シュト13とはちがった伝承に立っている。ヤシュトでは解放されるもの はダエーナー「婦女子」であった。ギリシャではプロメーテウスがカウ カソス山にゼウスによって縛られる。しかし，ゼウスにとってかれは重 大な子言を知るために，解放されることになる。プロメーテウスの肝臓 を毎日くう鷲を殺したへーラクレースが解放者と考えうるならば，ここ にも䦔争がみられる。いずれにしても, ギリシャ神話における「解き放 たれたプロメーテウス」の話の筋は, メソポ夕ミヤの例から較べると， かなり発展している。日本では天の岩戸つまり，メソポタミヤの神と同 じように山にかくれた天照大神を解放するのは天手力男命で，天鈿女命 がそばにいる。いずれも天孫降臨に従った神である。天照大神は，それ ではもとは男神であったかとなると，日本の学者の間にもいろいろな意 見がある。この神話を環太平洋の日蝕神話圈のひとつにかぞえるのが通 説である。しかし，自然民族の神話とはかなりのへだたりのある部分が あり，全面的には首肯しかねる。くわしい論考は後日を期したい。天照 大神の対偶と考えられるスサノヨノ命は，天の岩戸がくれのあと，根の 国で八岐大蛇を殺し，クシナダ姫をえている。天手力男とスサノタとは もとは同じ神格であったのかも知れない。天照大神が，ほんらいの女神 であったなら，クシナ多姫と同じ神格であったのかも知れない。解放さ れる神が女性であったり，男性であったりして，一定しないのは民族誌 の示すとおりである。日本神話では話の筋が 2 つの部分でそれぞれ展開 しているようである。ただ，闘争のテーマは，天の岩戸の変の前に， ス サノヨが天の斑駒の皮を機屋に投げ込む話にみられる。まだらの表象が 
通過儀礼においてみられるのは，先稿「古代イランの犬」で述べておい た。仏教の袈裟（kaçāya）に類する万葉集の語については「あらたまの その他について」( 岩倉具実教授退職記念論文集 べておいた。天の岩戸神話は，日蝕に関するものとしても，年の変り目 の神話にはちがいない。スサノタノ命の天の斑駒や八岐大蛇の話がこれ に前後してつけられていることに注目すればよいと思う。かりに，岩戸 神話を冬至のころの太陽神話との習合とみれば，それは新賞祭の神話的 実現であったと考えられうるであろう。大嘗祭における久米舞で演ぜら れるもぎ戦は即位礼にさいして行なわれる闘争儀礼にほかならない。い っぽう，この日に演ぜられる隼人が水に溺れて苦しむさまをあらわして いるが，おそらくこれも，近東の「死なんとする神」の日本的なあらわれ であると考えられる。「岩がくれ」した神の前で演ずるドラマが，このよ うな形であらわされたと考えられる。

イランのシーア派が行なうモハッラム（回教1月）10日のアーシュー ラー祭の中に,メソポタミヤーシリヤの Attis-Kybele 型の儀礼の伝統 が残っていることは，ヨーロッパの学者の指摘するところである。自分 が問題にしょうとするのは，10日正月ともいえるこの日にカルバラーで 歴史的合戦が行なわれたことである。もぎ戦ではなくて実際の戦闘がな されたことは，やはりある種の信念によるものと考えなければならない。 1 月10日は, 太陽暦と太陰暦の差日による推移であることは先稿で述べ ておいた。モハッラム1日から10日までが祭日であって，10日目が最大 の祭となり, 悽惨な受難の行列がみられる。H. Massé, 前掲書, 122ペー ジ以下に，この祭についてのヨーロッパの旅行家たちのくわしい記録お よび著者の注およびビブリオグラフィーがある。この10日は天国の屝は 開かれており，この10日間に死んだ者は楽に天国へ行ける。シーア・イ ラン人の間には, ゾロアスター教のフラワルティーカーンが形を変えて 生きていると考えられる。マセ 126 ページ以下のアーシューラーの日の 
記述から要約するとつぎのようになる。行列の先頭には軍隊がラッパを 吹いて先導した。その後に，騎馬の人々に引かれた馬飾りされた馬(複) がつづき，色とりどりの布がぶらさがっているアッバースの手（金属性 の）のついた棒をもった人がつづく。このあとに，俘囚やさまざまな負 傷をした人物，毛髮を切った人物，胸にあいくちのささった首のないホ セインの死体などがつづく。ホセインの死体のそばには豹が横たわって いる。さいごに，ホセインの子カーセムの婚姻の室を頭にのせた人がつ づく。室の中には稚子が入っている。人々はこぶしで胸を，鎖が束ねら れた払子ようのもので背を打ち, 刃物で前頭部を傷つけながら受難行列 に参加する。アラブに扮した一団が，テントの婦女子と分捕品を馬に乗 せて逃げようとする。このさいに闘争が行なわれる。アーシューラーの 日に闘争やけんかについては，歴代の旅行家に記録されている。2つの グループの闘争が起ると，外交使節が入ってとりなすのが注目される。 1786年の Franklinの記録（マセ，122ページ注 2 ）や，Wilsonの記録 (同，134-5ページ)がある。後者では，外交使節がタブリーズの皇太子 のもとに行き，そのとりなしで，現実の囚人が釈放される。世界各地で みられる，新年，即位礼あるいはエポックの変り目に行なわれる大赦の ひとつである。この日に，オマルの人形がふみくだかれ，夕方には焼き 棄てられる。興味のあるのは17世紀の Della Valleの記録である。それ によると，この日に貧しい人は土に穴を掘り，首だけを出してそれを土 器でおおう。

以上のごく簡単なモハッラム10日の行事をみても，それが再生儀礼の 伝統を受けついでいることがわかる。アッバースの手や豹（まだらの聖 獣であって，その表象に意味がある）は，エーゲ文明の再生儀礼にすで にみられるものである。神聖婚，哀悼傷身，幽閉者の解放，闘争，Uと 形の破棄一ここではイスラーム的な変形を受けて，仇敵オマルの像と なっている—, 土穴からの再生, 容器, ここれらのひとつひとつは機 
会があれば別に論じたいと思う。

自分は，古代イランのハマスパスマエーダ祭が年末の闘争祭で再生儀 礼のひとつであることを論証してみた。 


\section{A Mock Battle in Ancient Iran}

\section{Eiichi IMOTO}

There are about 11 days between the solar year and the lunar year, and about 5 days between the solar year and the 360-day year. Later calendars of various areas of the world have remainders of the 5th day, the 10th or the 13th day New Years, while some nations have remainders of the archaic New Years of the 8th or the 13th day of the 12th month. Iranian people who adopted the 365-day vague year calendar suffered inconvenience after many years as al-Bērūni has remarked some hundred years after. It is probable that astronomers observed five fixed points on the ecliptic and made them available for the farmers. These fixed points are the five gasanbars which the writer has tried to interpret philologically and ethnologically.

The ancient Iranians had the ten days' end of the year as well as the five days' one, the Hamaspathmaeda feast, in the last five days of the year. It is evident that there was a Harmageddon (Armageddon) battle of the good and the evil in Iran too, as the Gatha points out, and as a ritual there should have been a mock battle among the Zoroastrians to pass the eschatological end of the year. The writer furnishes an ethnographical proof that the Hamaspathmaeda feast must have been a feast where the fathers back from heavens fought against Ahriman's army and people played a drama realizing the battle. 